\title{
- IIIIIIIIIITा \\ CHEMICAL SCIENCES \\ Phenolic content and antioxidant capacity of infusions herbs: Optimization of phenolic extraction and HPLC-DAD method
}

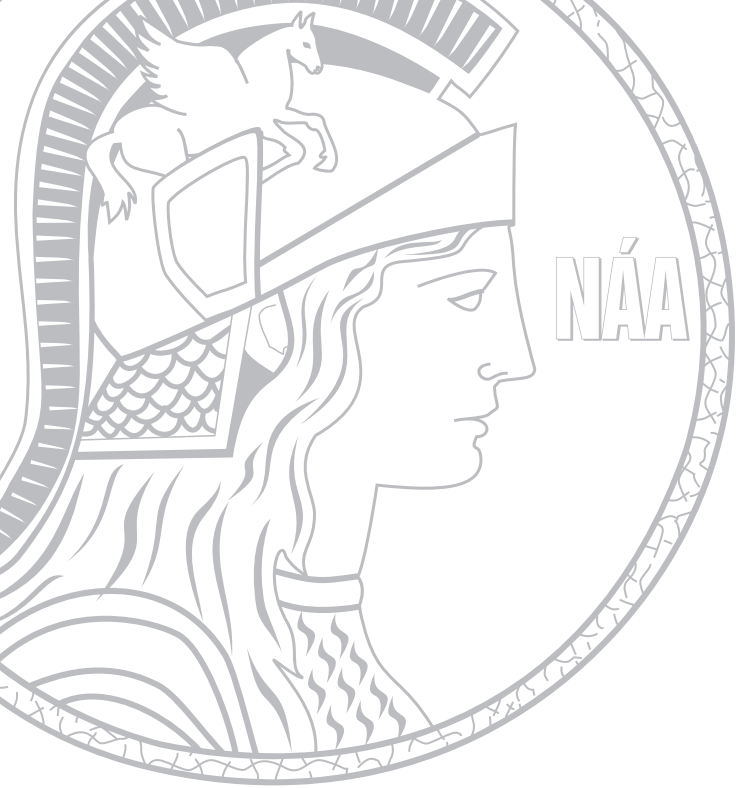

\author{
BÁRBARA E.A. DE MAGALHÃES \& WALTER N.L. DOS SANTOS
}

\begin{abstract}
The aim of this work was to investigate the phenolic content and antioxidant capacity of infusions of commercial herb samples (fennel, anise, peppermint, lemon grass and lemon balm) popularly consumed in Brazil. The infusion preparation for phenolic extraction was optimized using multivariate planning. Spectrophotometric methods were used to determine in vitro antioxidant activity and total phenolic and flavonoid content. Peppermint infusions had higher phenolic content and antioxidant potential. It was developed and validated a method by HPLC-DAD for the determination of caffeine, phenolic acids and flavonoids and applied for the analysis of the composition of the infusions. Higher concentrations were obtained for chlorogenic and p-coumaric phenolic acids and for flavonoids rutin and catechin. Principal Components Analysis and Hierarchical Cluster Analysis were applied for the comparative evaluation of the phenolic composition of the infusions. The multivariate analyzes indicate that the phenolic profile for the samples of the same species tend to present greater similarities in relation to other herbs and one of the analyzed samples, commercialized as anise, does not belong to the P. anisum species.
\end{abstract}

Key words: antioxidant capacity, HPLC, infusion, optimization, phenolic compounds.

\section{INTRODUCTION}

Plants are natural sources of phenolic antioxidant compounds, which may occur in all of its parts, such as seeds, roots, bark, leaves and fruits (Shahidi \& Ambigaipalan 2015). In most studies, plant extracts are prepared with solvents unsuitable for human consumption, therefore, they cannot be used as a food source of antioxidants (Erkekoglou et al. 2017).

Infusions and decoctions (beverages popularly called "teas") are excellent food sources of natural antioxidants. The preparation method of these beverages favors the extraction of the phenolic compounds of the plant. The infusions are prepared by the addition of heated or boiling water over parts of the plant, while the decoctions involve the boiling of the herb (Fotakis et al. 2016, Pérez et al. 2014).

The investigation of the phenolic profile and antioxidant capacity of the teas is important for the correlation of its composition with the beneficial health effects to which they are associated. The antioxidant capacity of the teas depends on the preparation process of the beverage and the species from which it was prepared, due to the fact that the content of phenolic compounds varies according to the species and because they present different antioxidant activities (Zielinski et al. 2014, Shahidi \& Ambigaipalan 2015, Fotakis et al. 2016). It is also important to investigate the properties of teas from commercial samples to provide 
consumers with information that may support their choice of product.

A wide variety of analytical methods can be used to determine bioactive phenolics. In the last twenty years, High Performance Liquid Chromatography (HPLC) has been extensively used for the separation and characterization of phenolic compounds. The choice of column is preferably C18 reverse phase (Acosta-Estrada et al. 2014). To detect and quantify phenolic compounds the chromatographic system can be equipped with various detectors such as ultraviolet/visible (UV/VIS), refractive index, fluorescence and mass spectrometry. The diode array detector (DAD) is widely used to elucidate the phenolic profile of plant materials. The determination of total phenolics and antioxidant capacity has been carried out predominantly by UV-Vis spectrophotometry (Haminiuk et al. 2012, Santos et al. 2017).

In this sense, the present work had the objective of optimizing the tea preparation by the infusion method and to investigate the phenolic antioxidant content in infusions of commercial samples of herbs commonly consumed in Brazil. For this, a simple DAD-coupled HPLC separation methodology was developed and validated to determine phenolic acids, flavonoids and caffeine. Using UV-Vis spectrophotometric methods, the total phenolic content, total flavonoid content and antioxidant capacity of the infusion samples were determined.

\section{MATERIALS AND METHODS}

\section{Reagents}

Caffeine, (+) catechin, rutin, quercetin, kaempeferol, ellagic, gallic, p-coumaric, chlorogenic and caffeic acids from sigma Chemical Company (St. Louis, USA). HPLC grade methanol, glacial acetic acid, 2,2-diphenyl1-picrylhydrazyl (DPPH), 2,2'-azinobis (3-ethylbenzthiazoline-6-sulphonic acid) (ABTS) from Merck (Darmstadt, Germany). Ethanol, methanol, phosphoric acid, sodium carbonate, potassium persulfate, aluminum chloride from Synth (São Paulo, Brazil). Ultrapure water was obtained from the Gehaka Master P\&D purification system (São Paulo, Brazil).

\section{Samples}

Samples of herbs of five species packaged in sachets were bought in commercial establishments in Salvador (Bahia, Brazil): Foeninculum vulgare (fennel), Pimpinella anisum (anise), Cymbopogon citratus (lemon grass), Mentha piperita (peppermint) and Melissa officinalis (lemon balm). Samples of anise were also obtained in bulk and as spice. Three different brands were acquired for each species and three different lots for each brand.

\section{Optimization strategy of the extraction process}

The traditional preparation of the teas does not have well-established conditions. The optimization of this extraction process was performed using multivariate experimental design, for which a fennel sample was used and the sample mass was fixed in $2 \mathrm{~g}$. The spectrophotometric method was used for the determination of total phenolic compounds, the results were calculated using a calibration curve of gallic acid and expressed as extracted mass of phenol, in milligrams. Central Point (CP) triplicates were performed to determine the experimental error of the planning.

Initially, two-level complete factorial planning was used to evaluate the interaction and principal effect of the variables involved in the infusion preparation: infusion time, volume and temperature of water. The $2^{3}$ factorial planning matrix is presented in Table I with coded and actual values. 
Table I. $2^{3}$ complete factorial planning matrix.

\begin{tabular}{|c|c|c|c|}
\hline Experiment & Infusion time (min) & Water volume (mL) & Water temperature (oC) \\
\hline 1 & $-1(3)$ & $-1(80)$ & $-1(28)$ \\
\hline 2 & $+1(15)$ & $-1(80)$ & $-1(28)$ \\
\hline 3 & $-1(3)$ & $+1(200)$ & $-1(28)$ \\
\hline 4 & $+1(15)$ & $+1(200)$ & $+1(100)$ \\
\hline 5 & $-1(3)$ & $-1(80)$ & $+1(100)$ \\
\hline 6 & $+1(15)$ & $-1(80)$ & $+1(100)$ \\
\hline 7 & $-1(3)$ & $+1(200)$ & $+1(100)$ \\
\hline 8 & $+1(15)$ & $+1(200)$ & $0(64)$ \\
\hline $9(C P)$ & $0(9)$ & $0(140)$ & $0(64)$ \\
\hline $10(C P)$ & $0(9)$ & $0(140)$ & $0(64)$ \\
\hline $11(C P)$ & $0(9)$ & $0(140)$ & \\
\hline
\end{tabular}

CP: Central point.

The Doehlert matrix was used to determine the optimal conditions of the statistically significant variables in $2^{3}$ factorial design (water temperature and infusion time). The volume of water was fixed in $140 \mathrm{~mL}$. The Doehlert matrix is presented in Table II with coded and actual values.

\section{Extraction procedure}

Infusion preparation resembles the traditional preparation method of the beverage, employing optimized conditions. In a closed recipient, $140 \mathrm{~mL}$ of boiling water was added to $2 \mathrm{~g}$ of herb. After $17 \mathrm{~min}$ at rest, it was filtered and the infusion obtained was frozen at $-20^{\circ} \mathrm{C}$ for further analysis.

\section{Total phenolic content}

The total content of phenolic compounds was determined by the colorimetric method with adaptations (Aimvijarn et al. 2018, OliveiraJúnior et al. 2017). The determinations were performed in triplicate. The Folin-Denis reagent was prepared by solubilizing $5 \mathrm{~g}$ of sodium tungstate dehydrate and $1 \mathrm{~g}$ of phosphomolybdic acid in $38 \mathrm{~mL}$ of ultrapure water and $2.5 \mathrm{~mL}$ of phosphoric acid. The mixture was refluxed for 2h, then cooled and diluted (Santos et al. 2017).

$3.1 \mathrm{~mL}$ of water and $200 \mu \mathrm{L}$ of Folin-Denis reagent were added to $100 \mu \mathrm{L}$ of tea, and after $5 \mathrm{~min}, 600 \mu \mathrm{L}$ of $7.5 \%(\mathrm{w} / \mathrm{v})$ aqueous sodium carbonate solution was also added, all being shaken at the end. After 60 min (set time in kinetic test) in the dark and at room temperature, the absorbance was measured in a UV-Vis spectrophotometer (Biospectro, Brazil) 
Table II. Doehlert matrix.

\begin{tabular}{|c|c|c|}
\hline Experiment & Infusion time (min) & Water temperature (o) $)$ \\
\hline 1 & $+0.866(20)$ & $-0.5(70)$ \\
\hline 2 & $+0.866(20)$ & $+0.5(90)$ \\
\hline 3 & $0(15)$ & $-1(60)$ \\
\hline 4 & $0(15)$ & $+1(100)$ \\
\hline 5 & $-0.866(10)$ & $-0.5(70)$ \\
\hline 6 & $-0.866(10)$ & $+0.5(90)$ \\
\hline $7(C P)$ & $0(15)$ & $0(80)$ \\
\hline $8(C P)$ & $0(15)$ & $0(80)$ \\
\hline $9(C P)$ & $0(15)$ & $0(80)$ \\
\hline
\end{tabular}

CP: Central point.

at $760 \mathrm{~nm}$. The results were calculated using a calibration curve of gallic acid (0-10 $\mathrm{mg} \mathrm{L}^{-1} ; \mathrm{y}=$ $0.0824 x-0.0216 ; R=0.9985)$ and expressed as milligrams equivalents of gallic acid per liter (mg L'-1 GAE).

\section{Total flavonoid content}

The total flavonoid content was determined using the colorimetric method by with hexahydrated aluminum chloride (Santos et al. 2017). $2.4 \mathrm{~mL}$ of $2 \%(\mathrm{w} / \mathrm{v})$ aluminum chloride methanolic solution and $1.56 \mathrm{~mL}$ of methanol were added to $40 \mu \mathrm{L}$ of tea, then shaken. After $30 \mathrm{~min}$ (time set in kinetic test) the absorbance readings were made at $415 \mathrm{~nm}$ in a UV-Vis spectrophotometer (Biospectro, Brazil). The determinations were performed in triplicate. The results were calculated using a quercetin calibration curve (0-10 mg L'; $y=0.0534 x-0.0036 ; R=0.9975)$ and the results were expressed as milligrams equivalents of quercetin per liter ( $\mathrm{mg} \mathrm{L}^{-1} \mathrm{QE}$ ).

\section{In vitro antioxidant activity}

The antioxidant activity was determined by radical sequestration methodologies (Santos et al. 2017): DPPH (Rufino et al. 2007a) and ABTS ${ }^{+}$ (Rufino et al. 2007b). The determinations were performed in triplicate. In a dark environment, $100 \mu \mathrm{L}$ of tea was added to $3.9 \mathrm{~mL}$ of DPPH 0,06 $\mathrm{mM}$ methanolic solution (prepared only on the day of analysis), then shaken at the end. After the time established in the kinetic test (30 min for peppermint and lemon balm samples and 60 min for the others), the absorbances were read at $515 \mathrm{~nm}$ in a UV-Vis spectrophotometer (Biospectro, Brazil).

The solution of the $\mathrm{ABTS}^{++}$radical was prepared from the reaction of $5 \mathrm{~mL}$ of $7 \mathrm{mM}$ ABTS aqueous solution with $88 \mu \mathrm{L}$ of $140 \mathrm{mM}$ aqueous potassium persulfate solution and kept in the dark at room temperature for 16 h. The absorbances were read in a UV-Vis spectrophotometer (Biospectro, Brazil) at a wavelength of $734 \mathrm{~nm}$. Using ethanol, $1 \mathrm{~mL}$ of the ABTS $^{+}$solution was diluted to the absorbance of $0.70 \pm 0.05$. In a dark environment, $30 \mu \mathrm{L}$ of tea was added to $3 \mathrm{~mL}$ of the diluted $\mathrm{ABTS}^{+}$solution, then shaken. After $6 \mathrm{~min}$, the absorbances were read at $734 \mathrm{~nm}$. 
The radical-scavenging activity was expressed as the inhibition percentage (Rebey et al. 2019), calculated as follows: $\%$ inhibition = $100 \times$ (ABS blank - ABS sample)/ABS blank.

\section{HPLC-DAD analyses}

A high-performance liquid chromatograph Promimence model (Shimadzu Scientific Instruments, Japan) equipped with a high pressure quaternary pump (LC-20AD model), degasser (DGU-20A5 model), diode array detector (SPD-20A model), automatic sampler (SIL-20A model), heating furnace for column (CTO-20A model) and communication module (CBM-20A model), operated by LCsolutions software, was used. Lichrospher ${ }^{\circledR}$ RP 18 column $(5 \mu \mathrm{m}, 4.6$ x $250 \mathrm{~mm}$ ) from Agilent (Germany) was also used.

Factors affecting the chromatographic separation (elution gradient, mobile phase flow and column temperature) were studied and optimized univariate. The efficiency of the separation was evaluated based on the chromatographic resolution, which is influenced by the experimental parameters: retention factor, separation factor (or selectivity) and number of theoretical plates (or efficiency) (Santos et al. 2017). These parameters were calculated from the injection of a mixture of all compound standards (2 $\mathrm{mg} \mathrm{L}^{-1}$ ): caffeine, phenolic acids (gallic, ellagic, chlorogenic, caffeic, $p$-coumaric) and flavonoids (catechin, rutin, quercetin, kaempferol).

Chromatographic separation was performed

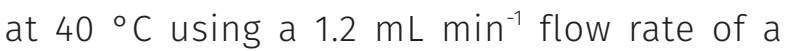
solvent mixture for gradient elution: ultrapure water with $1 \%(\mathrm{v} / \mathrm{v})$ glacial acetic acid (A) and methanol HPLC grade (B). The gradient program was as follows: $100 \%-50 \%$ A (0-5 min); $50-38 \%$ A (5-7.5 min); 38-34\% A (7.5-8 min); 34\%-29\% A (8-12.5 min); $29-37 \%$ A (12.5-13 $\mathrm{min}) ; 37 \%-50 \%$ A (13-15 min); 50\%-100\% A (15-17 min); 100\% A (17$20 \mathrm{~min})$.
After the optimization of the chromatographic separation method, the validation for HPLC-DAD determinations was performed according to the official guidelines, based on linearity, limits of detection and quantitation, precision (repeatability and intermediate precision), accuracy (recovery) and robustness.

The attempt to identify the chromatographic peaks was performed by comparing their retention times and UV spectra with those of reference standards. UV chromatograms were acquired at different wavelengths, from 260 to $360 \mathrm{~nm}$. The analysis of infusions was performed in triplicate, using an injection volume of $20 \mu \mathrm{L}$. Table III shows the chromatographic parameters for the analysis of phenolic acids, flavonoids and caffeine.

\section{Statistical analyzes}

The Principal Components Analysis (PCA) and Hierarchical Cluster Analysis (HCA), implemented in STATISTICA 7.0 software (Stat-Soft Inc., USA), were used to evaluate comparatively the composition of the analyzed samples, based on data standardized centered on the average.

\section{RESULTS AND DISCUSSION}

\section{Optimization of the extraction process}

The $2^{3}$ complete factorial design indicated that the infusion time and water temperature factors are statistically significant, as well as the interaction between them, as it can be seen in the Pareto graph (Figure 1). The positive values of the effects of infusion time and water temperature indicate that, within the domain studied, the response (mass of extracted phenolics) rise with the rise of these variables.

The Pareto graph also shows that the influence of the temperature variable on the response is greater than that of the infusion time 
Table III. Chromatographic parameters for the analysis of phenolic acids, flavonoids and caffeine by HPLC-DAD.

\begin{tabular}{|c|c|c|c|c|c|c|}
\hline Compound & $\begin{array}{l}\text { Retention } \\
\text { time (min) }\end{array}$ & $\begin{array}{l}\text { UV Band } \\
\text { (nm) }\end{array}$ & Regression equation & $\begin{array}{l}\text { Correlation } \\
\text { coefficient }\end{array}$ & $\begin{array}{c}\text { LOD } \\
\left(\mathrm{mg} \mathrm{L}^{-1}\right)\end{array}$ & $\begin{array}{c}\text { LOQ } \\
\left(\mathrm{mg} \mathrm{L}^{-1}\right)\end{array}$ \\
\hline Rutin & 10.24 & 260 & $y=26432 x+1514.2$ & 0.9969 & 0.20 & 0.59 \\
\hline Ellagic acid & 10.76 & 260 & $y=90516 x+2771.3$ & 0.9961 & 0.22 & 0.67 \\
\hline Gallic acid & 5.84 & 272 & $y=52131 x+7867.3$ & 0.9933 & 0.21 & 0.64 \\
\hline Caffeine & 9.43 & 272 & $y=116947 x+8415.1$ & 0.9947 & 0.23 & 0.68 \\
\hline Catechin & 7.94 & 280 & $y=9507 x+1384.4$ & 0.9940 & 0.17 & 0.52 \\
\hline p-Coumaric acid & 9.86 & 310 & $y=81911 x+10573$ & 0.9946 & 0.23 & 0.69 \\
\hline Chlorogenic acid & 8.38 & 330 & $y=46190 x-3557$ & 0.9952 & 0.25 & 0.74 \\
\hline Caffeic acid & 8.92 & 330 & $y=91755 x+8536.7$ & 0.9938 & 0.17 & 0.50 \\
\hline Quercetin & 12.01 & 360 & $y=57490 x+3550$ & 0.9954 & 0.13 & 0.38 \\
\hline Kaempferol & 13.11 & 360 & $y=69686 x+1743$ & 0.9978 & 0.16 & 0.50 \\
\hline
\end{tabular}

LOD: Limit of detection. LOQ: limit of quantification.

variable. The Doehlert matrix for optimization was chosen for that reason, since this planning allows the variables to be studied at different levels (Ferreira et al. 2004). The temperature variable was studied in five levels, and the time variable was studied in three levels. Since the volume of water did not prove to be a significant variable for the studied process, its value was fixed in $140 \mathrm{~mL}$ for the optimization step.

The data of the Doehlert planning were processed using the real values, generating the quadratic model that is represented by the response surface (Figure 2 ) in which the maximum condition is observed. The critical values (maximum stationary points) are $99.67^{\circ} \mathrm{C}$ for water temperature and $17.02 \mathrm{~min}$ for infusion time.

A reliable way to evaluate the quality of fit of the model is to use the Analysis of Variance (ANOVA). ANOVA showed non-significant lack of fit, significant regression, high coefficient of determination $\left(R^{2}=0.973\right)$ and low pure error and residuals. Thus, it can be inferred that there is agreement between the real values and the values predicted by the model, which describes the studied region well and may be used to infer conclusions about the optimal region.

For the validation of the infusion extraction method, analytical parameters were evaluated using HPLC-DAD analyses. Analytical curves with addition of standard to infusions were linear in the studied range ( 0.5 to $2.5 \mathrm{mg} \mathrm{L}^{-1}$ ), obtaining correlation coefficients higher than 0.99 . Accuracy was estimated in recovery trials for the addition of standard at three concentration levels. The values obtained for recovery are within the acceptable range of $70 \%$ to $120 \%$ (Ribani et al. 2004, Azevedo et al. 2019), reflecting the accuracy of the method.

\section{Spectrophotometric determinations}

The results for the determinations of total phenolic compounds (TPC), total flavonoids (TF) and in vitro antioxidant activity are presented in Table IV. TPC ranged from 72.32 to $557.70 \mathrm{mg} \mathrm{L}^{-1}$, TF from 29.28 to $202.50 \mathrm{mg} \mathrm{L}^{-1}$, inhibition of DPPH ranged from 43.29 to $92.29 \%$ and inhibition of ABTS from 20.42 to $99.95 \%$. 


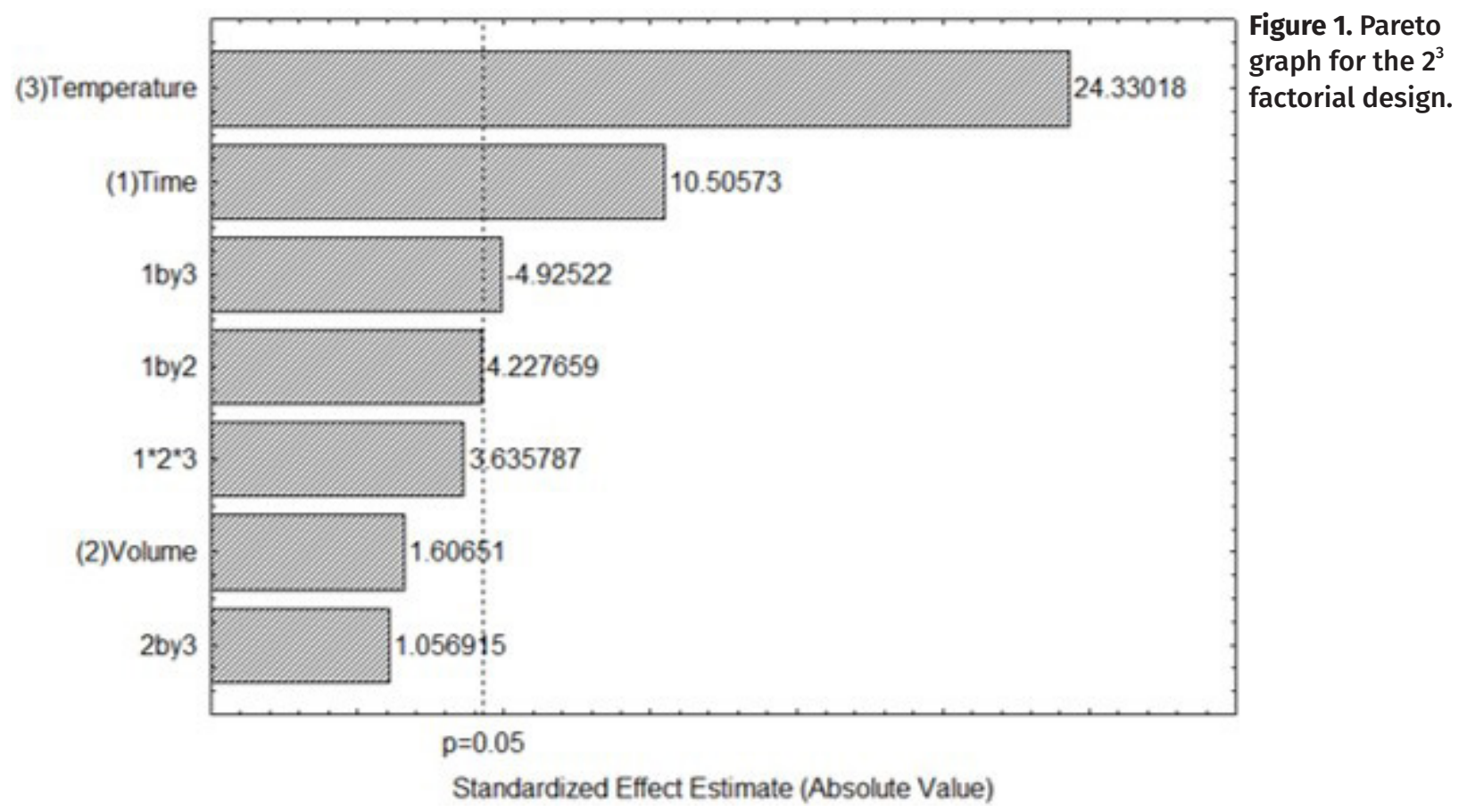

The variation of the phenolic content and the antioxidant activity observed for the infusions of different species is related to the fact that the phenolic content varies according to the species. The high standard deviations obtained reflect the difference between the lots. The observed variation can be attributed to several factors, such as the geographical origin, the environmental and seasonal conditions during the development of the plant, the manufacturing conditions adopted by the companies, such as storage and drying process (the phenolic composition is sensitive to temperature changes), among others (Dias et al. 2013, Zielinski et al. 2014, Costa et al. 2016). Climatic conditions in the same geographical region differ at different seasons, which may also result in changes in the chemical compositions of tea (Zhao et al. 2017).

In addition to the previously mentioned factors, the tea preparation process also affects its phenolic composition, which may justify the observed differences between the data presented in this paper and others described in the literature. These factors may also justify the observed differences between the results obtained in this study in comparison with others available in the literature, as well as the fact that different extraction methods are used, since the process of preparation of the infusion also affects its composition (Fotakis et al. 2016). There are no studies that relate the phenolic composition of anise with different commercial forms.

Zielinski et al. 2014 determined total phenolics and total flavonoids in infusions of samples in sachets of anise, lemon grass and peppermint. On average, the total phenolic compounds content was, respectively, 100.45, 147.12 and $470.07 \mathrm{mg} \mathrm{L}^{-1}$; these values agree with some of the samples of these species in this work. For the total flavonoid content, 34.09, 46.35 and $125.57 \mathrm{mg} \mathrm{L}^{-1}$ were obtained on average, respectively, for one of the studied samples of anise and lemon grass, but lower than that obtained for the peppermint samples. 


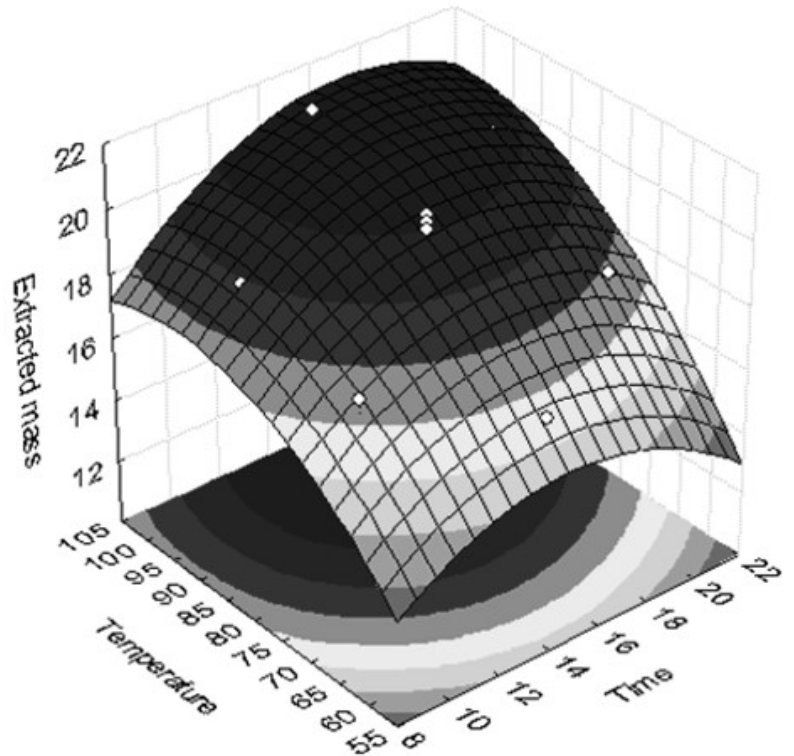

Figure 2. Response surface for Infusion time $\mathrm{x}$ Water temperature.

Pérez et al. 2014 identified levels of 29.42 to $30.33 \mu \mathrm{g} \mathrm{mL} \mathrm{L}^{-1}$ for total phenolics and from 8.60 to $8.95 \mu \mathrm{g} \mathrm{mL} \mathrm{m}^{-1}$ for total flavonoids in infusions of peppermint leaves, lower than the values determined for infusions of this species in this work and the study by Zielinski et al. 2014. Trendafilova et al. 2010 determined the total phenolic content of infusions of commercial fennel and lemon balm samples of, respectively, 112.2 and $1126.5 \mathrm{mg} \mathrm{L}^{-1} \mathrm{GAE}$. The results for fennel are close to one of the samples from this study, but the values obtained for lemon balm are lower than the study mentioned.

Regarding the antioxidant activity, Zielinski et al. 2014 determined the percentage reduction of the DPPH - radical for commercial infusions of anise, lemon grass and peppermint of, respectively, $14.30 \%, 17.10 \%$, and $35.24 \%$. Trendafilova et al. 2010 verified $11.76 \%$ for the inhibition of DPPH by infusion of fennel. These values are lower than obtained in this work for infusions of these same species. For infusion of lemon balm, Trendafilova et al. 2010 verified $91.65 \%$ for the inhibition of DPPH, a value close to that obtained for one of the lemon balm samples of this study. Cheel et al. 2005 determined the percentage of inhibition of DPPH by infusion of lemon grass of $40.2 \%$, which is lower than that obtained in this study and by Figueirinha et al. 2008 , of $62.3 \%$, similar to the one presented in this study.

\section{Optimization and validation of HPLC-DAD methodology}

In order to obtain a better separation and resolution of the chromatographic peaks, successive gradient modifications were tested, keeping the composition of the mobile phase fixed (methanol and acidified water with 1\% $\mathrm{v} / \mathrm{v}$ acetic acid) and the chromatographic conditions $\left(40{ }^{\circ} \mathrm{C}\right.$ and $\left.1.0 \mathrm{~mL} \mathrm{~min}{ }^{-1}\right)$, changing only the proportions of the solvents. After 13 modifications the optimal gradient was established.

Applying the optimized gradient, the effect of solvent flow on the separation was studied. The standard mixture was injected using flow rates of 0.8 to $1.4 \mathrm{~mL} \mathrm{~min}^{-1}$. The increase in the flow up to $1.2 \mathrm{~mL} \mathrm{~min}^{-1}$ favored the separation and provided better resolution values for most of the analytes, being this the optimal condition established.

Applying the optimized gradient and flow rate, the chromatographic column temperature was studied. The standard mixture was injected employing temperatures of 38 to $44^{\circ} \mathrm{C}$. At $40^{\circ} \mathrm{C}$ better resolution values were obtained for most of the analytes, and this temperature condition was established as optimal.

The efficiency of the chromatographic separation in the established optimal conditions was evaluated based on the parameters: resolution, retention factor, separation factor and number of theoretical plates. It was obtained for all analytes: resolution > 1.5, number of theoretical plates $>2000$, retention factor $>0.5$ and separation factor $>1.0$. The 
Table IV. Results of the spectrophotometric determinations.

\begin{tabular}{|c|c|c|c|c|}
\hline Samples & $\begin{array}{l}\text { Total phenolics (mg } \\
\left.\mathrm{L}^{-1} \mathrm{GAE}\right)\end{array}$ & $\begin{array}{l}\text { Total flavonoids (mg } \\
\left.\mathrm{L}^{-1} \mathrm{QE}\right)\end{array}$ & $\begin{array}{c}\text { DPPH } \\
\text { (\% inhibition) }\end{array}$ & $\begin{array}{c}\text { ABTS } \\
\text { (\% inhibition) }\end{array}$ \\
\hline MR & $496.63 \pm 4.28$ & $147.82 \pm 6.13$ & $92.29 \pm 0.23$ & $99.95 \pm 0.07$ \\
\hline MS & $185.08 \pm 2.88$ & $85.77 \pm 1.32$ & $66.41 \pm 10.74$ & $43.49 \pm 1.92$ \\
\hline$M C$ & $169.89 \pm 15.65$ & $57.05 \pm 7.66$ & $58.33 \pm 9.89$ & $33.62 \pm 3.23$ \\
\hline $\mathrm{HO}$ & $557.70 \pm 52.40$ & $191.89 \pm 27.91$ & $92.17 \pm 0.15$ & $99.95 \pm 0.07$ \\
\hline$H M$ & $446.09 \pm 41.29$ & $155.68 \pm 34.00$ & $91.44 \pm 0.65$ & $99.71 \pm 0.20$ \\
\hline $\mathrm{HF}$ & $502.60 \pm 7.19$ & $202.50 \pm 15.69$ & $92.05 \pm 0.23$ & $99.76 \pm 0.13$ \\
\hline$C R$ & $170.60 \pm 17.99$ & $80.15 \pm 7.76$ & $65.68 \pm 2.70$ & $47.53 \pm 3.74$ \\
\hline $\mathrm{CO}$ & $87.60 \pm 5.51$ & $38.95 \pm 2.76$ & $47.36 \pm 0.26$ & $22.60 \pm 2.16$ \\
\hline CM & $102.08 \pm 36.56$ & $63.92 \pm 24.30$ & $64.91 \pm 19.47$ & $29.20 \pm 6.86$ \\
\hline FR & $127.86 \pm 30.68$ & $45.51 \pm 5.77$ & $74.98 \pm 2.87$ & $38.94 \pm 5.32$ \\
\hline $\mathrm{FO}$ & $114.08 \pm 3.19$ & $29.28 \pm 0.44$ & $43.29 \pm 2.41$ & $27.68 \pm 1.95$ \\
\hline $\mathrm{FC}$ & $149.49 \pm 30.32$ & $43.95 \pm 6.89$ & $74.86 \pm 12.62$ & $32.67 \pm 9.69$ \\
\hline $\mathrm{DM}$ & $272.32 \pm 14.18$ & $61.11 \pm 20.97$ & $79.54 \pm 17.99$ & $40.08 \pm 11.85$ \\
\hline $\mathrm{DL}$ & $98.37 \pm 17.91$ & $35.83 \pm 3.61$ & $57.86 \pm 8.85$ & $22.65 \pm 2.62$ \\
\hline DF & $149.23 \pm 18.25$ & $47.38 \pm 6.62$ & $79.37 \pm 6.25$ & $32.57 \pm 4.12$ \\
\hline DK & $74.61 \pm 1.19$ & $29.90 \pm 1.17$ & $45.42 \pm 3.01$ & $20.42 \pm 1.31$ \\
\hline DN & $107.20 \pm 5.23$ & $33.02 \pm 2.21$ & $57.38 \pm 6.92$ & $24.41 \pm 1.70$ \\
\hline $\mathrm{DH}$ & $113.20 \pm 2.88$ & $31.15 \pm 1.92$ & $66.48 \pm 3.88$ & $23.88 \pm 2.64$ \\
\hline DE & $72.32 \pm 13.37$ & $31.46 \pm 0.76$ & $43.84 \pm 0.97$ & $23.74 \pm 4.91$ \\
\hline DB & $101.72 \pm 0.75$ & $31.77 \pm 0.44$ & $61.02 \pm 0.26$ & $22.74 \pm 1.75$ \\
\hline DV & $91.39 \pm 1.85$ & $32.71 \pm 1.17$ & $50.76 \pm 0.75$ & $21.13 \pm 0.24$ \\
\hline
\end{tabular}

M: lemon balm; H: Peppermint; C: lemon grass; F: fennel; D: anise. The second letter of the sample acronym distinguishes the brand. Mean \pm standard deviation, $\mathrm{n}=3$.

values obtained were satisfactory (Azevedo et al. 2019), therefore, the method is selective and the separation is efficient for caffeine, phenolic acids and flavonoids studied.

The analytical curves generated by injections in triplicate of the working solutions containing all analytes at six concentration levels ( 0.1 to $2.5 \mathrm{mg} \mathrm{L}^{-1}$ ). Linearity was determined by the correlation coefficients of mean of the three areas measured with the respective concentration. As shown in Table III, the correlation coefficients $(r>0.99)$ indicate that all calibration curves had good linearity within the test ranges. Limit of detection corresponds to the lowest concentration of the analyte that produces a response three times higher than the noise. Limit of quantification indicates the lowest concentration of analyte that can be accurately measured. The limits of detection and of quantification ranged between 0.13 and $0.25\left(\mathrm{mg} \mathrm{L}^{-1}\right)$ and 0.38 a $0.74\left(\mathrm{mg} \mathrm{L}^{-1}\right)$, respectively, as shown in Table III.

Instrumental accuracy (repeatability) was measured by 10 consecutive injections of the 
standard mixture. Intermediate precision was measured by injecting of the standard mixture into three nonconsecutive days under the same measurement conditions. Precision was expressed in terms of relative standard deviation. Values of 0.15 to $5.7 \%$ were obtained for the repeatability and from 1.07 to $6.61 \%$ for the intermediate precision, indicating that the method allows an accurate analysis of the phenolic bioactive and caffeine.

For the recovery assays, in triplicate, a sample of each species (previously analyzed) was enriched with the solutions of the standards at three levels concentrations (1, 3 and $5 \mathrm{mg} \mathrm{L}^{-1}$ ) and subjected to extraction. Recovery values were obtained from $70.92 \% \pm 0.56$ to $119.30 \% \pm$ 0.27 , within the acceptable limit considering the complexity of the sample, indicating that the method is accurate.

The robustness of the method was evaluated by injecting a mixture of standards using two-level complete factorial design $\left(2^{2}\right)$, with triplicate of the central point (optimal conditions established), varying the composition of the mobile phase (percentage of acetic acid) and temperature of the chromatographic column. In the generated Pareto graph (Figure 3) it can be seen that the factors and the interaction between them are not statistically significant at the 95\% confidence level, indicating that the method is robust within the experimental domain studied, for the variation of $20 \%$ in the acetic acid concentration in the mobile phase and $5 \%$ temperature variation.

According to these results, it is indicated that the proposed method is appropriated for the detection and quantification of the studied compounds in infusions. As the validation process was carried out with solutions of the caffeine, phenolic (gallic, ellagic, chlorogenic, caffeic, p-coumaric) and flavonoid standards (catechin, rutin, quercetin, kaempferol), the validated method can be applied in several matrices for the separation, identification and quantification of these analytes.

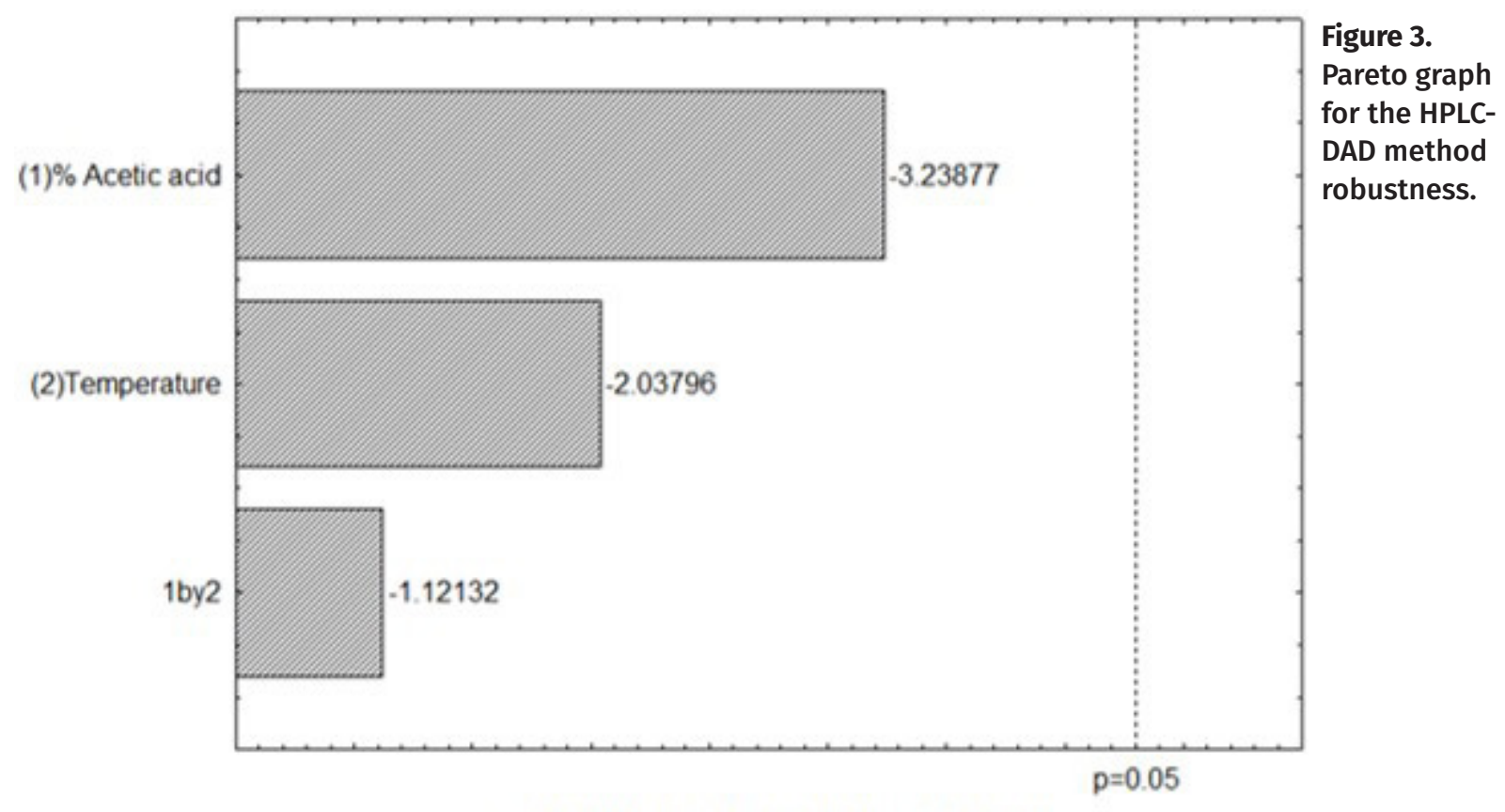

Standardized Effect Estimate (Absolute Value) 


\section{Analysis of infusions by HPLC-DAD}

In this work, the investigation of the infusions composition of commercial samples was done using HPLC-DAD analysis and the concentrations obtained for phenolic acids, flavonoids and caffeine are shown in Table $V$. The highest concentrations of phenolic acids were verified for chlorogenic $\left(0.35-35.41 \mathrm{mg} \mathrm{L}^{-1}\right)$ and p-coumaric (1.01 - $\left.10.43 \mathrm{mg} \mathrm{L}^{-1}\right)$ acids. Among the phenolic acids present in plants, derivatives of hydroxynamic acids such as chlorogenic and p-coumaric acids are more common in relation to hydroxybenzoic acids, such as ellagic and gallic acids (Shahidi \& Ambigaipalan 2015). Among the flavonoids, the highest concentrations were rutin $\left(0.25\right.$ - $\left.107.49 \mathrm{mg} \mathrm{L}^{-1}\right)$ and catechin (0.23 $\left.15.68 \mathrm{mg} \mathrm{L}^{-1}\right)$.

As observed in the spectrophotometric determinations, there was great variability between the results for the different species, justified by the variation of the phenolic profile according to the species, and the variation for different brands may be related to the geographical origin, environmental conditions, the manufacturing and preparation of the tea (Dias et al. 2013, Costa et al. 2016, Fotakis et al. 2016).

Zielinski et al. 2014 determined chlorogenic acid in infusions of anise (26.24 $\left.\mathrm{mg} \mathrm{L}^{-1}\right)$ and peppermint $\left(3.25 \mathrm{mg} \mathrm{L}^{-1}\right)$ in a concentration similar to that verified for samples of this work. The concentrations of chlorogenic acid infused with lemon grass (37.97 $\mathrm{mg} \mathrm{L}^{-1}$ ) and quercetin (59.77 $\mathrm{mg} \mathrm{L}^{-1}$ ) in peppermint infusions are higher than in this study.

Pérez et al. 2014 determined concentrations of caffeic acid ( 0.67 to $1.04 \mu \mathrm{g} \mathrm{mL}^{-1}$ ) and quercetin (1.10 to $2.28 \mu \mathrm{g} \mathrm{mL}^{-1}$ ) in peppermint infusion, respectively, similar to and higher than that determined in this study. Marques \& Farah 2009 quantified caffeic acid (0.01 to $0.16 \mathrm{mg}$ in $200 \mathrm{~mL}$ of infusion) in lemon balm infusions at concentrations lower than that observed in the samples analyzed in this study.

The absence of caffeine was expected in the infusions of fennel, anise, lemon grass, lemon balm and peppermint, considering that their teas have a carminative effect, which is not consistent with the stimulant effect promoted by caffeine. No studies were found indicating the presence of this substance in the species studied. However, caffeine was identified in infusions of the samples of all batches of a lemon balm brand and in only two of the analyzed batches of a peppermint brand. Therefore, the caffeine content in these samples may be the result of contamination in the manufacturing process.

When comparing the chromatograms of all the anise samples, it was verified that only one of them (DN) presented a phenolic profile different from the others, which presented the same chromatographic profile independent of the commercial form, as shown in Figure 4. In addition to the chromatographic profile, the physical appearance of the DN samples (elongated fruit) also differs significantly from the other anise samples (small and round fruits). However, the description of the composition for the species (Pimpinella anisum) and the part of the plant are not supplied by all brands. The scientific name of the species is not shown on the sample packaging.

In Brazil, the term "erva-doce" is used to designate two species: anise (Pimpinella anisum) and fennel (Foeniculum vulgare). Although they belong to the same botanical family (Apiaceae) and share many similar characteristics, P. anisum and F. vulgare present different phenolic profiles. Thus, the infusion chromatographic profiles of the DN sample and a fennel sample were compared, as shown in Figure 4c. 
Table V. Concentration ( $\mathrm{mg} \mathrm{L}^{-1}$ ) of phenolics and caffeine in infusions.

\begin{tabular}{|c|c|c|c|c|c|c|c|c|c|c|}
\hline Sample & $\begin{array}{l}\text { Ellagic } \\
\text { Acid }\end{array}$ & $\begin{array}{l}\text { Gallic } \\
\text { Acid }\end{array}$ & $\begin{array}{c}\text { p-Coumaric } \\
\text { Acid }\end{array}$ & $\begin{array}{c}\text { Chlorogenic } \\
\text { Acid }\end{array}$ & $\begin{array}{l}\text { Caffeic } \\
\text { Acid }\end{array}$ & Rutin & Catechin & Quercetin & Kaempferol & Caffeine \\
\hline MR & $\begin{array}{c}0.83 \pm \\
0.18\end{array}$ & n.d. & $1.97 \pm 0.56$ & $1.68 \pm 0.67$ & $\begin{array}{c}6.63 \pm \\
0.79\end{array}$ & $\begin{array}{c}107.49 \\
\pm \\
19.60\end{array}$ & $\begin{array}{c}2.72 \pm \\
0.28\end{array}$ & n.d. & n.d. & $\begin{array}{c}7.38 \pm \\
1.04\end{array}$ \\
\hline MS & $\begin{array}{c}0.81 \pm \\
0.09\end{array}$ & n.d. & $6.49 \pm 0.20$ & $0.35 \pm 0.04$ & n.d. & $\begin{array}{r}15.14 \\
\pm 0.18\end{array}$ & $\begin{array}{l}5.04 \pm \\
3.15\end{array}$ & n.d. & $0.79 \pm 0.04$ & n.d. \\
\hline$M C$ & $\begin{array}{c}1.80 \pm \\
0.04\end{array}$ & n.d. & $3.99 \pm 0.59$ & $0.57 \pm 0.31$ & $\begin{array}{c}0.61 \pm \\
0.20\end{array}$ & $\begin{array}{r}13.32 \\
\pm 0.83\end{array}$ & $\begin{array}{c}5.41 \pm \\
0.94\end{array}$ & n.d. & $0.56 \pm 0.06$ & n.d. \\
\hline $\mathrm{HO}$ & $\begin{array}{c}1.00 \pm \\
0.31\end{array}$ & n.d. & $2.78 \pm 0.30$ & $0.96 \pm 0.41$ & $\begin{array}{l}7.94 \pm \\
3.46\end{array}$ & $\begin{array}{c}40.55 \\
\pm \\
12.59\end{array}$ & n.d. & $0.62 \pm 0.08$ & n.d. & n.d. \\
\hline $\mathrm{HM}$ & $\begin{array}{c}5.89 \pm \\
3.19\end{array}$ & $\begin{array}{c}0.25 \pm \\
0.03\end{array}$ & $1.18 \pm 1.32$ & $5.37 \pm 1.42$ & $\begin{array}{c}4.84 \pm \\
1.00\end{array}$ & $\begin{array}{r}43.59 \\
\pm 7.45\end{array}$ & $\begin{array}{c}0.66 \pm \\
0.24\end{array}$ & n.d. & n.d. & n.d. \\
\hline $\mathrm{HF}$ & $\begin{array}{c}1.41 \pm \\
0.10\end{array}$ & n.d. & $2.94 \pm 0.19$ & $3.07 \pm 0.10$ & $\begin{array}{c}5.77 \pm \\
0.19\end{array}$ & $\begin{array}{r}45.94 \\
\pm 2.02\end{array}$ & $\begin{array}{c}0.35 \pm \\
0.03\end{array}$ & $0.50 \pm 0.01$ & n.d. & n.d. \\
\hline$C R$ & $\begin{array}{c}0.55 \pm \\
0.07\end{array}$ & n.d. & $3.19 \pm 0.35$ & $12.07 \pm 1.49$ & $\begin{array}{c}1.28 \pm \\
0.14\end{array}$ & $\begin{array}{c}3.68 \pm \\
0.50\end{array}$ & $\begin{array}{c}0.23 \pm \\
0.04\end{array}$ & n.d. & n.d. & n.d. \\
\hline $\mathrm{CO}$ & n.d. & n.d. & $2.44 \pm 0.07$ & $4.94 \pm 0.23$ & $\begin{array}{c}0.22 \pm \\
0.02\end{array}$ & $\begin{array}{c}0.25 \pm \\
0.02\end{array}$ & n.d. & n.d. & n.d. & n.d. \\
\hline $\mathrm{CM}$ & n.d. & n.d. & $2.20 \pm 0.14$ & $19.97 \pm 9.74$ & n.d. & $\begin{array}{l}1.86 \pm \\
2.54\end{array}$ & n.d. & n.d. & n.d. & n.d. \\
\hline FR & $\begin{array}{c}0.73 \pm \\
0.14\end{array}$ & $\begin{array}{c}0.87 \pm \\
0.33\end{array}$ & $9.65 \pm 0.82$ & $11.53 \pm 2.45$ & n.d. & $\begin{array}{r}22.02 \\
\pm 0.72\end{array}$ & $\begin{array}{c}5.64 \pm \\
1.66\end{array}$ & n.d. & n.d. & n.d. \\
\hline FO & $\begin{array}{c}0.29 \pm \\
0.03\end{array}$ & $\begin{array}{c}1.76 \pm \\
0.16\end{array}$ & $1.76 \pm 0.16$ & $4.94 \pm 0.74$ & $\begin{array}{c}0.27 \pm \\
0.10\end{array}$ & $\begin{array}{c}9.00 \\
\pm \\
0.90\end{array}$ & $\begin{array}{c}15.68 \pm \\
0.87\end{array}$ & n.d. & n.d. & n.d. \\
\hline $\mathrm{FC}$ & $\begin{array}{c}0.81 \pm \\
0.24\end{array}$ & n.d. & $10.43 \pm 2.63$ & $12.53 \pm 3.65$ & n.d. & $\begin{array}{l}24.54 \\
\pm 3.75\end{array}$ & $\begin{array}{c}5.17 \pm \\
0.22\end{array}$ & n.d. & n.d. & n.d. \\
\hline DM & n.d. & $\begin{array}{c}0.72 \pm \\
0.17\end{array}$ & $2,18 \pm 0.93$ & $35.41 \pm 16.28$ & $\begin{array}{c}0.77 \pm \\
0.46\end{array}$ & $\begin{array}{c}6.14 \pm \\
2.76\end{array}$ & $\begin{array}{c}9.11 \pm \\
2.57\end{array}$ & n.d. & n.d. & n.d. \\
\hline $\mathrm{DL}$ & n.d. & n.d. & $1.25 \pm 0.22$ & $12.35 \pm 2.94$ & n.d. & $\begin{array}{c}2.50 \pm \\
0.38\end{array}$ & $\begin{array}{c}3.31 \pm \\
0.74\end{array}$ & n.d. & n.d. & n.d. \\
\hline DF & n.d. & $\begin{array}{c}0.84 \pm \\
0.27\end{array}$ & $1.83 \pm 0.34$ & $26.21 \pm 3.02$ & $\begin{array}{c}0.44 \pm \\
0.08\end{array}$ & $\begin{array}{c}4.76 \pm \\
0.89\end{array}$ & $\begin{array}{c}7.19 \pm \\
0.85\end{array}$ & n.d. & n.d. & n.d. \\
\hline DK & n.d. & n.d. & $1.20 \pm 0.12$ & $8.87 \pm 0.91$ & n.d. & $\begin{array}{c}1.98 \pm \\
0.10\end{array}$ & $\begin{array}{c}2.98 \pm \\
0.28\end{array}$ & n.d. & n.d. & n.d. \\
\hline DN & $\begin{array}{c}0.70 \pm \\
0.05\end{array}$ & n.d. & $7.30 \pm 0.33$ & $11.06 \pm 0.42$ & n.d. & $\begin{array}{l}23.99 \\
\pm 1.57\end{array}$ & $\begin{array}{c}5.38 \pm \\
0.51\end{array}$ & n.d. & n.d. & n.d. \\
\hline $\mathrm{DH}$ & n.d. & n.d. & $1.01 \pm 0.04$ & $14.28 \pm 0.96$ & n.d. & $\begin{array}{c}3.94 \pm \\
0.23\end{array}$ & $\begin{array}{c}4.77 \pm \\
0.11\end{array}$ & n.d. & n.d. & n.d. \\
\hline $\mathrm{DE}$ & n.d. & n.d. & $1.08 \pm 0.01$ & $9.41 \pm 0.36$ & n.d. & $\begin{array}{c}3.27 \pm \\
0.43\end{array}$ & $\begin{array}{c}3.60 \pm \\
0.11\end{array}$ & n.d. & n.d. & n.d. \\
\hline DB & n.d. & n.d. & $1.19 \pm 0.10$ & $14.27 \pm 0.36$ & n.d. & $\begin{array}{c}3.26 \pm \\
0.56\end{array}$ & $\begin{array}{c}5.20 \pm \\
0.23\end{array}$ & n.d. & n.d. & n.d. \\
\hline DV & n.d. & n.d. & $1.48 \pm 0.51$ & $14.77 \pm 3.86$ & n.d. & $\begin{array}{c}5.31 \pm \\
1.76\end{array}$ & $\begin{array}{l}4.86 \pm \\
2.76\end{array}$ & n.d. & $0.44 \pm 0.22$ & n.d. \\
\hline
\end{tabular}

M: lemon balm; H: Peppermint; C: lemon grass; F: fennel; D: anise. The second letter of the sample acronym distinguishes the brand. $n$.d.: not detected or below limit of detection. Mean \pm standard deviation, $n=3$. 
As shown by the comparison of the chromatograms, Figure 4 explains that the phenolic profile of the DN sample infusion differs from the profile of the other anise samples and resembles that of the fennel sample. In view of this, it is suggested that sample DN, marketed as anise, does not belong to the P. anisum species like the other samples, it actually is another species called F. vulgare.

\section{Multivariate analysis (PCA and HCA)}

The multivariate statistical methods simplify the interpretation of the studied data through the construction of alternative variables or indices that condense the original information of the data, allowing us to obtain the maximum information of the chemical data and that are not demonstrated by the conventional analysis (Santos et al. 2017).
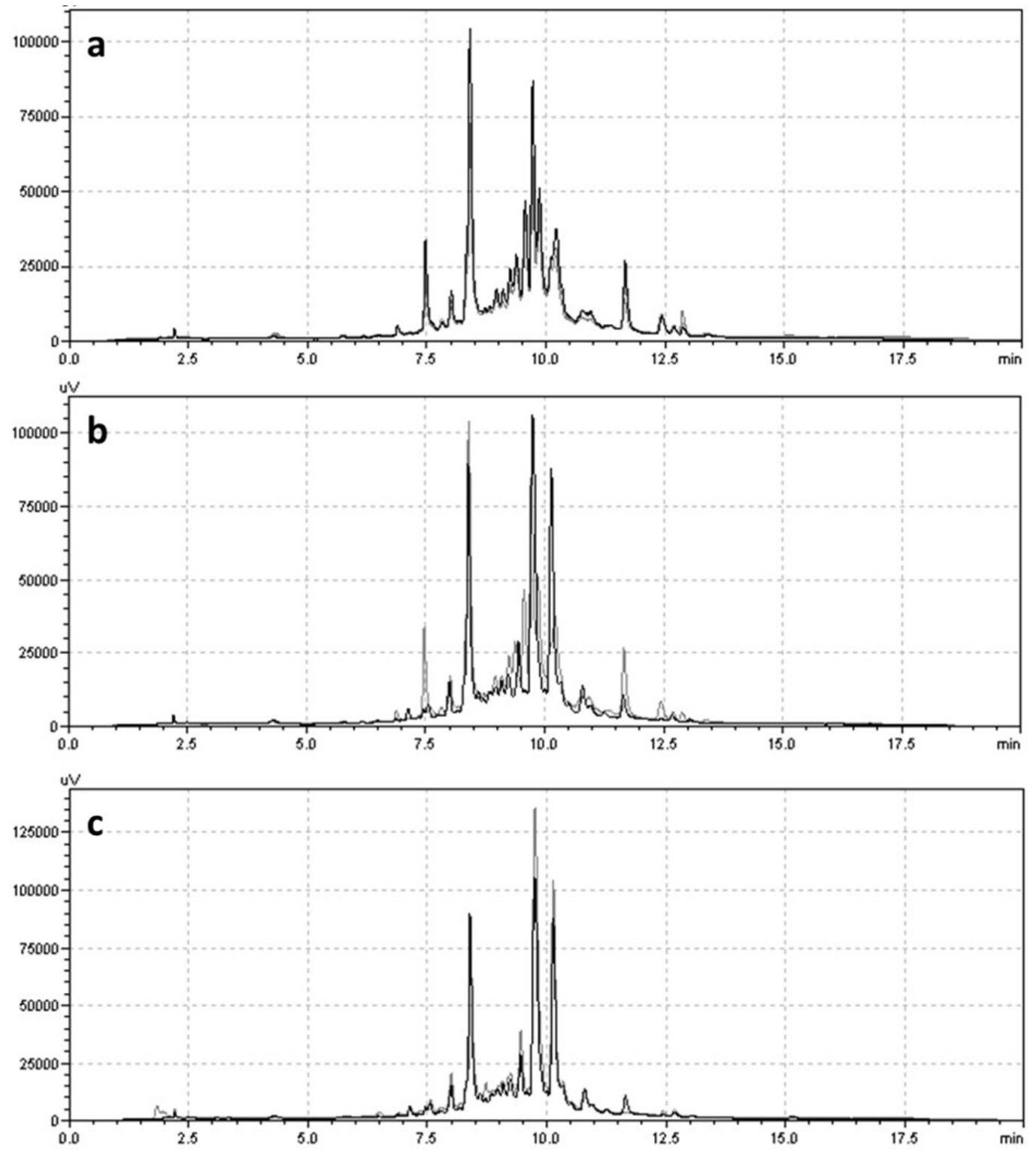

Figure 4. Comparison of chromatograms in wavelength $310 \mathrm{~nm}$ : (a) Overlap of chromatograms of infusions of anise samples (DH, DE, DL) in different commercial forms (spice, bulk and sachet); (b) Overlapping of the infusion chromatograms of samples DN (black) and DH (gray); (c) Overlapping of the infusion chromatograms of samples DN (black) and fennel (gray). 
The multivariate statistical methods, PCA and HCA (Figure 5), were used to comparatively evaluate the composition of the analyzed samples. In the PCA, were selected the principal components (PCS) whose eigenvalues are equal or greater than to 1. For the analysis of components, the non-rotated matrix was used, being verified that there is no redundancy and that each original variable is significant only for one of the PCS.

For the PCA of the infusions of different species commercialized in sachets, 4 PCs were significant. PC1 explains $38.99 \%$ of the data variance, while PC2 explains $17.07 \%$, PC3 14.87\% and PC4 11.10\%. The results for PCA are expressed by the graph of scores for PC1 x PC2, shown in the Figure $5 \mathrm{a}$, which explain most of the total variance of the experimental data (56.06\%), being satisfactory for extracting information. The graph shows the separation of a sample of lemon balm (MR) and a group of samples of peppermint ( $\mathrm{HF}, \mathrm{HO}, \mathrm{HM})$ from the other samples. This separation is consistent with the results of the spectrophotometric determinations, in which the peppermint and MR samples were distinguished for having higher phenolic content and antioxidant activity than the other samples.

The PCA analysis indicates that the segregation of the MR sample is due to the much higher concentration of rutin and the
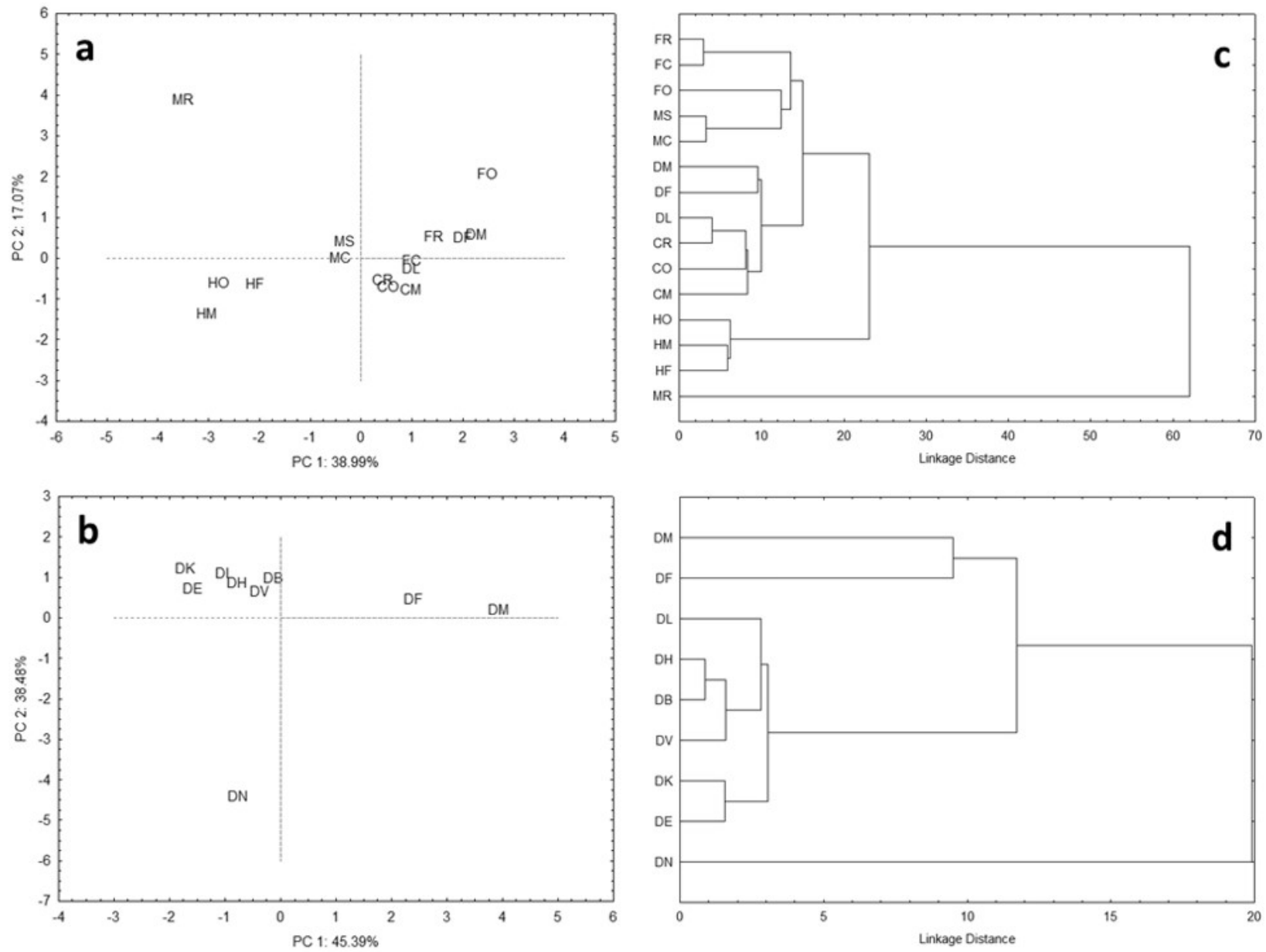

Figure 5. Scores plots (PC1 x PC2) for infusions of (a) samples commercialized in sachets and (b) different commercial forms of anise. Dendrograms for infusions of (c) samples in sachets and (d) anise. 
presence of caffeine, while in the case of the group of peppermint samples, the segregation was mainly due to the presence of quercetin, not detected in the other samples.

For the PCA of infusions of different commercial forms of anise, only two PCs showed an eigenvalue greater than 1. PC1 explains $45.39 \%$ of the total variation and the PC2 explains 38.48\%, thus, the graph PC1 x PC2 (Figure 5b) explains $83.87 \%$ of the variability of the experimental data. The graph of scores shows the segregation of the DN sample, mainly due to the fact that it did not contain kaempferol and because it had much higher concentrations of rutin and ellagic and $p$-coumaric acids. The separation of the group of samples in sachets is explained by their higher concentrations of catechin and gallic and chlorogenic acids. The other samples presented similarities in relation to the majority of the analytes, which justifies the formation of the largest group.

The results for HCA are presented as dendrogram, in which the smaller the distance between the groupings, the greater the similarity. In this study, it was used the Euclidean distance for the distance measure and the Single Linkage method as linkage rule.

In the dendrogram of the infusions of different species commercialized in sachets (Figure $5 c$ ), we can observe the separation of a sample of lemon balm (MR), a group of samples of peppermint ( $\mathrm{HF}, \mathrm{HO}, \mathrm{HM})$ and the other of infusions with lower phenolic contents (other samples), which corroborates the results obtained in the determinations spectrophotometric and PCA.

The dendrogram of infusions of different commercial forms of anise (Figure $5 \mathrm{~d}$ ) shows the same groups obtained by PCA. The multivariate analyzes explain the discrepancy between the composition of the sample DN in relation to the other samples, providing another subsidy to affirm that this sample does not belong to the species Pimpinella anisum, as previously discussed.

\section{CONCLUSION}

The experimental designs applied were efficient for the study of the factors involved in the preparation of infusion and for establishing optimum conditions for the extraction of phenolic compounds. The HPLC-DAD proposed method is appropriated for the detection and quantification of phenolic acids, flavonoids and caffeine and can be applied in several matrices. The results of the investigation of the antioxidant composition of infusions of commercial samples showed that it can vary greatly depending on the species, commercial form, brand and lot of the samples, as many factors may affect the phenolic content. The multivariate analysis methods used in this study were adequate to evaluate the composition of the infusions analyzed and indicate that the phenolic profile for the samples of the same species tend to present greater similarities in relation to other herbs.

\section{Acknowledgments}

This study was supported by Coordenação de Aperfeiçoamento de Pessoal de Nivel Superior (CAPES) and Conselho Nacional de Desenvolvimento Científico e Tecnológico (CNPq).

\section{REFERENCES}

ACOSTA-ESTRADA BA, GUTIÉRREZ-URIBE JA \& SERNA-SALDÍVAR SO. 2014. Bound phenolics in foods, a review. Food Chem 152: 46-55.

AIMVIJARN P, RODBOON T, PAYUHAKRIT W \& SUWANNALERT P. 2018. Nymphaea pubescens induces apoptosis, suppresses cellular oxidants-related cell invasion in B16 melanoma cells. Pharm Sci 24(3): 199-206. 
AZEVEDO RSA, TEIXEIRA BS, SAUTHIER MCS, SANTANA MVA, SANTOS WNL \& SANTANA DA. 2019. Multivariate analysis of the composition of bioactive in tea of the species Camellia sinensis. Food Chem 273: 39-44.

CHEEL J, THEODULOZ C, RODRÍGUEZ I \& SCHMEDA-HIRSCHMANN G. 2005. Free radical scavengers and antioxidants from lemongrass (Cymbopogon citratus (DC.) Stapf.). J Agric Food Chem 53(7): 2511-2517.

COSTA G, GRANGEIA H, FIGUEIRINHA A, FIGUEIREDO IV \& BATISTA MT. 2016. Influence of harvest date and material quality on polyphenolic content and antioxidant activity of Cymbopogon citratus infusion. Ind Crops Prod 83: 738-745.

DIAS MI, BARROS L, DUEÑAS M, PEREIRA E, CARVALHO AM, ALVES RC, OLIVEIRA BPP, SANTOS-BUELGA C \& FERREIRA ICFR. 2013. Chemical composition of wild and commercial Achillea millefolium L. and bioactivity of the methanolic extract, infusion and decoction. Food Chem 141(4): 4152-4160.

ERKEKOGLOU I, NENADIS N, SAMARA E \& MANTZOURIDOU FT. 2017. Functional teas from the leaves of Arbutus unedo: Phenolic content, antioxidant activity, and detection of efficient radical scavengers. Plant Foods Hum Nutr 72(2): 176-183.

FERREIRA SLC, SANTOS WNL, QUINTELLA CM, NETO BB \& BOSQUESANDRA JM. 2004. Doehlert matrix: a chemometric tool for analytical chemisty - review. Talanta 63(4): 1061-1067.

FIGUEIRINHA A, PARANHOS A, PÉREZ-ALONSO JJ, SANTOSBUELGA C \& BATISTA MT. 2008. Cymbopogon citratus leaves: Characterization of flavonoids by HPLC-PDA-ESI/MS/ MS and an approach to their potential as a source of bioactive polyphenols. Food Chem 110(3): 718-728.

FOTAKIS C ET AL. 2016. Metabolic and antioxidant profiles of herbal infusions and decoctions. Food Chem 211: 963-971.

HAMINIUK CWI, MACIEL GM, PLATA-OVIEDO MSV \& PERALTA RM. 2012. Phenolic compounds in fruits - an overview. Int J Food Sci Technol 47(10): 2023-2044.

MARQUES V \& FARAH A. 2009. Chlorogenic acids and related compounds in medicinal plants and infusions. Food Chem 113(4): 1370-1376.

OLIVEIRA-JÚNIOR RG, FERRAZ CAA, SOUZA GR, GUIMARÃES AL, OLIVEIRA AP, LIMA-SARAIVA SRG, ROLIM LA, ROLIM-NETO PJ \& ALMEIDA JRGS. 2017. Phytochemical analysis and evaluation of antioxidant and photoprotective activities of extracts from flowers of Bromelia laciniosa (Bromeliaceae). Biotechnol Biotechnol Equip 31(3): 600-605.

PÉREZ MGF, ROCHA-GUZMÁN NE, MERCADO-SILVA E, LOARCAPIÑA G \& REYNOSO-CAMACHO R. 2014. Effect of chemical elicitors on peppermint (Mentha piperita) plants and their impact on the metabolite profile and antioxidant capacity of resulting infusions. Food Chem 156: 273-278.

REBEY IB, WANNES WA, KAAB SB, BOURGOU S, TOUNSI MS, KSOURI $R$ \& FAUCONNIER ML. 2019. Bioactive compounds and antioxidant activity of Pimpinella anisum L. accessions at different ripening stages. Sci Hortic 246: 453-461.

RIBANI M, BOTTOLI CBG, COLLINS CH, JARDIM ICSF \& MELO LFC. 2004. Validação em métodos cromatográficos e eletroforéticos. Quim Nova 27(5): 771-780.

RUFINO MSM, ALVES RE, BRITO ES, MORAIS SM, SAMPAIO CG, PÉREZ-JIMÉNEZ J \& SAURA-CALIXTO FD. 2007a. Metodologia Científica: Determinação da Atividade Antioxidante Total em Frutas pela Captura do Radical Livre DPPH. Embrapa. Comunicado Técnico Online 127. Disponivel em https://www.embrapa.br/busca-de-publicacoes/-/ publicacao/426953/metodologia-cientificadeterminacao-da-atividade-antioxidante-total-emfrutas-pela-captura-do-radical-livre-dpph. Acessado em abril de 2017.

RUFINO MSM, ALVES RE, BRITO ES, MORAIS SM, SAMPAIO CG, PÉREZ-JIMÉNEZ J \& SAURA-CALIXTO FD. 2007b. Metodologia Científica: Determinação da atividade antioxidante total em frutas pela captura do radical livre ABTS $\cdot+$. Embrapa. Comunicado Técnico Online 128. Disponível em https://www.embrapa.br/busca-de-publicacoes/-/ publicacao/426954/metodologia-cientificadeterminacao-da-atividade-antioxidante-total-emfrutas-pela-captura-do-radical-livre-abts. Acessado em abril de 2017.

SANTOS WNL, SAUTHIER MCS, SANTOS AMP, SANTANA DA, AZEVEDO RSA \& CALDAS JC. 2017. Simultaneous determination of 13 phenolic bioactive compounds in guava (Psidium guajava L.) by HPLC-PAD with evaluation using PCA and Neural Network Analysis (NNA). Microchem J 133: 583-592.

SHAHIDI F \& AMBIGAIPALAN, P. 2015. Phenolics and polyphenolics in foods, beverages and spices: Antioxidant activity and health effects - A review. J Funct Foods 18(B): 820-897.

TRENDAFILOVA A, TODOROVA M, VASSILEVA E \& IVANOVA D. 2010. Comparative study of total phenolic content and radical scavenging activity of conventionally and organically grown herbs. Bot Serb 34(2): 133-136.

ZHAO H, YU C \& LI M. 2017. Effects of geographical origin, variety, season and their interactions on minerals in tea for traceability. J Food Compos Anal 63: 15-20.

ZIELINSKI AAF, HAMINIUK CWI, ALBERTI A, NOGUEIRA A, DEMIATE IM \& GRANATO D. 2014. A comparative study of the phenolic 
compounds and the in vitro antioxidant activity of different Brazilian teas using multivariate statistical techniques. Food Res Int 60: 246-254.

\section{How to cite}

MAGALHÃES BEA \& SANTOS WNL. 2020. Phenolic content and antioxidant capacity of infusions herbs: Optimization of phenolic extraction and HPLC-DAD method. An Acad Bras Cienc 92: e20190646. DOI 10.1590/00013765202020190646.

Manuscript received on June 7, 2019;

accpeted for publication on August 12, 2019

\section{WALTER N.L. DOS SANTOS ${ }^{1.2}$}

https://orcid.org/0000-0001-9773-6660

\section{BÁRBARA E.A. DE MAGALHÃES ${ }^{1,2}$}

https://orcid.org/0000-0001-9329-1967

${ }^{1}$ Universidade do Estado da Bahia, Departamento de Ciências Exatas e da Terra, Rua Silveira Martins, 2555, Cabula, 41195-001 Salvador, BA, Brazil

${ }^{2}$ Universidade Federal da Bahia, Departamento de Química Analítica, Instituto de Química, Av. Adhemar de Barros, s/n, Ondina, 40170-290 Salvador, BA, Brazil

Correspondence to: Walter Nei Lopes dos Santos

E-mail address: waltrs8@gmail.com

\section{Author contributions}

Both authors contributed to the study conception and design. Methodology, formal analysis and investigation, and writing (draft of the manuscript): Bárbara Elizabeth Alves de Magalhães. Supervision, funding acquisition, and writing (review and editing): Walter Nei Lopes dos Santos.

\section{(cc) BY}

